ORIGINAL ARTICLE

\title{
Influence of the tooth's geometry on the bandsaw's cutting power for Callycophyllum spruceanum wood
}

\author{
Influência da geometria do dente na potência de corte com serra de fita para \\ madeira Callycophyllum spruceanum

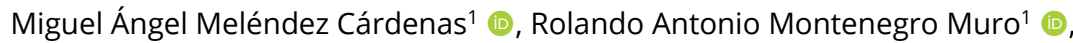

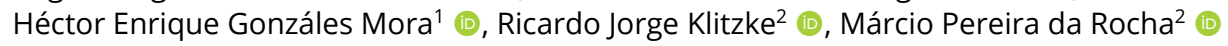 \\ ${ }^{1}$ Departamento Académico de Industrias Forestales, Universidad Nacional Agraria La Molina - UNALM, Lima, Perú \\ 2Departamento de Engenharia e Tecnologia Florestal, Universidade Federal do Paraná - UFPR, Curitiba, PR, Brasil
}

How to cite: Meléndez Cárdenas, M. Á., Montenegro Muro, R. A., Gonzáles Mora, H. E., Klitzke, R. J., \& Rocha, M. P. (2021). Influence of the tooth's geometry on the bandsaw's cutting power for Callycophyllum spruceanum wood. Scientia Forestalis, 49(130), e3560. https://doi.org/10.18671/scifor.v49n130.19

\begin{abstract}
The purpose of this work was to evaluate the effect of two bandsaw tooth models on the cutting power for the Callycophyllum spruceanum (capirona) wood, originated from a 20-year-old plantation in UcayaliPeru. The cutting power was measured during the resaw of 12 blocks of the wood under study, using two tooth shapes and three chip thicknesses. Additionally, for each resawed block, its moisture content, basic density, Janka side hardness, and silica content were determined to characterize the wood under study. The results proved that the tooth profile, the chip thickness, and the level of the commercial stem height significantly affected the useful cutting power, although the last factor did not have any interaction with the tooth profile nor with the chip thickness. They also have shown that cutting with medium and thick chip thicknesses decreases the useful power when the tooth shape is changed from hook to skip. In summary, the model called skip tooth stood out in comparison with the hook tooth because it saves energy during the resaw of a type of wood that is hard, fine-grained, and of high basic density, such as the one studied herein.
\end{abstract}

Keywords: Tooth profile; Rake angle; Chip thickness; Feed speed.

\begin{abstract}
Resumo
Este trabalho teve como objetivo avaliar o efeito de dois modelos de dente de serra de fita na potência de corte de madeira de Callycophyllum spruceanum (capirona) de uma plantação de 20 anos de idade em Ucayali-Peru. As medições da potência de corte foram realizadas durante a prensagem de 12 blocos de madeira em estudo, utilizando dois formatos de dente e três espessuras de cavacos. Além disso, para cada bloco de mesa, foram determinados o teor de umidade, densidade básica, dureza lateral da Janka e teor de sílica para caracterizar a madeira estudada. Os resultados mostraram que o perfil do dente, a espessura do cavaco e o nível de altura do fuste comercial influenciaram significativamente na potência útil de corte, embora o último fator não tenha mostrado interação com o perfil do dente ou com a espessura do cavaco. Ele também revelou que o corte de espessuras médias e grossas de cavacos diminuiu a potência útil ao mudar do formato de dente mareado para dente reto. Em resumo, o modelo chamado dente reto destacou-se sobre o dente mareado por permitir economia de energia durante o desdobro de uma madeira dura, pouco abrasiva e com alta densidade básica, como a estudada.
\end{abstract}

Palavras-chave: Perfil do dente; Ângulo de ataque; Espessura de cavacos; Velocidade de avanço.

\author{
Financial support: None \\ Conflict of interest: Nothing to declare. \\ Correspondig author: mmecd@lamolina.edu.pe \\ Received: 17 June 2020. \\ Accepted: 7 October 2020. \\ Editor: Paulo Henrique Müller Silva.
}

(i) This is an Open Access article distributed under the terms of the Creative Commons Attribution License, which permits unrestricted use,

c) distribution, and reproduction in any medium, provided the original work is properly cited. 


\section{INTRODUCTION}

Nowadays, Peru's wood industry employs several wood species, empirically and limited by scarce technical-scientific support, which results in the experimentation of industrial processing technologies with little-known species. This trial-and-error situation resulted in the low-paced evolution of the Peruvian tropical wood mechanical transformation caused by the industry's lack of technological information on optimal cutting conditions that would enable the development of a set of efficiency indicators in the processing of several timber species, limiting the cutting time, the edge wear, and the energy consumption, without the decrease of the surface's quality.

According to the Technological Innovation Center of Wood (CITE madera, 2012), much of the companies' efficiency and income losses are due to the consequences that generate unsolved problems, such as: low quality of lumber, loss of raw material and operational capability, overruns caused by an elevated replacement of blades and increase of energy consumption due to the greater number of cuts required to achieve the desired thickness, and increased cutting effort.

The cutting energy consumption urged us to pay more attention to the cutting power because it is directly related to the 80 lumber species currently sold on the Peruvian market, and because it can contribute to the implementation of an industrial processing guide for groups of similar species in their inherent cutting characteristics, which, therefore, can expand the wood industry's negotiation and investment horizons.

A wood that is present in the national and international market is the capirona (Calycophyllum spruceanum Benth) whose demand has a growing trend due to its technological characteristics and low cost (Lluncor et al., 2006). This species is commercialized in the region under the names of: ibiro moroti (Argentina), guayabochi (Bolivia), pau mulato (Brazil), guayabete (Colombia), corusicao (Ecuador) and araguato (Venezuela). In the estuarine region of the Amazon, it is common to find family micro-sawmills that explore and process this wood in a traditional way, mainly with the aim of producing pieces for civil construction. There is also the use of small diameter shafts in the construction of warehouses for the storage of tools and family agricultural production (Araújo et al., 2016).

The cutting process efficiency with bandsaw within the expected limits does not depend exclusively on the operation of the machine itself, but of a set of factors that affect the cutting effort, which, according to several researchers, are divided into three groups (Cartagena Agreement Board, 1989; Gonçalves, 2000; Garcia et al., 2002), which are: inherent to the wood's features, the work conditions, and the cutting tool.

Thus, the optimization of resources and tools can be achieved, establishing strict controls that enable the adjustment of some cutting parameters, such as the chip thickness, cutting speed, feed speed, and cutting height, to manufacture products of high quality and simultaneously reduce the costs related to energy consumption. Since the cutting height and the tool's features depend on the type of wood that will be cut, only the chip thickness can be adjusted to plan the cut (Vignote \& Martinez, 2006).

Sales (1990) explains that the cutting effort is directly proportional to the chip thickness for thicknesses between 0.2 and $2.8 \mathrm{~mm}$. The lower limit is limited by the proper cut zone, as the upper limit depends on the mechanical resistance of the teeth, of the blade, of the effects applied according to volumetric mass, and of the wood's moisture content.

The feed speed is one of elements employed to calculate the chip thickness and can vary from 10 to $30 \mathrm{~m} / \mathrm{min}$ for the automatic feed of small sawing machines or for the resawing of hardwoods with great diameters (Dalois, 1990). Melendez \& Valenzuela (2017) establish four height categories for the sawing of capirona to obtain the average feed speed required in each category, as presented below:

- $\quad$ Small (height under $30 \mathrm{~cm}$ ): $19.33 \mathrm{~m} / \mathrm{min}$

- Medium (height from 30 and under $50 \mathrm{~cm}$ ): $10.96 \mathrm{~m} / \mathrm{min}$

- High (height from 50 and under $70 \mathrm{~cm}$ ): $5.72 \mathrm{~m} / \mathrm{min}$

- Very high (height equal o above $70 \mathrm{~cm}$ ): $4.08 \mathrm{~m} / \mathrm{min}$

The variables that affect the sawing and resawing processes of each timber species are subjects of research, considering that they can provide parameters and indicators of their 
difficulty in the mechanical processing and, additionally, estimate with enough security ranks of energy consumption according to the wood's hardness and the geometry of the selected tooth.

Vital (2013) considers that the elements of a saw tooth that establish its shape or geometry should be specified according to the different factors that affect the cutting operation. Therefore, he underscores that the rake angle affects more the cutting capability in circular saws than in bandsaws whose cutting capability is established by their chip exit angle. He specifies that the resaw of hardwoods usually employs a chip exit angle around $12^{\circ}$ and that, in the case of denser wood, said angle should be smaller to increase the tooth's resistance.

The Forest Institute (1989) warns that when the tooth is too high in comparison with the distance between the teeth, the toothed part will vibrate and the saw will deviate from the intended cut. Dalois (1990) adds that the teeth's height should not be above 11 to 13 times the blade's thickness.

According to CITE madera (Technological Innovation Center of Wood, 2012), the hook tooth is strong and is proper for extremely hard woods. Tuset \& Duran (2007) also recommend said profile, especially for hardwoods due to its comparatively scarce throat. Nonetheless, the Forest Institute (1989) estimates that, due to its profile, it presents less resistance and is recommended for softwoods.

CITE madera (Technological Innovation Center of Wood, 2012) considers the skip profile as the ideal tooth shape, one that is usually proper both for hardwoods and softwoods. Its flatbased throat and large area reduces the risk of cracking. Dalois (1990) says that this profile, with the capability increase of the machine and of the bandsaw's blades, was gradually replaced by the PV shape tooth.

When different cutting conditions are employed, one expects that the geometry of the tool that generates less strength comes to be the most effective in the cut if the goal is to employ less power (Cristóvão et al., 2012). In this sense, the necessity to quantify and evaluate the energy consumption while cutting a hardwood like capirona, supports this research's purpose of evaluate the effect of two bandsaw tooth shapes in the cutting power of the Calycophyllum spruceanum wood, originated from a 20 -year-old plantation in Ucayali-Peru.

\section{MATERIAL AND METHODS}

The cutting test was performed in the Gestión Maderera SAC (GEMA) company, located at Huachipa, $14 \mathrm{~km}$ east from Lima, capital of Peru. The company sells timbers of Amazonian commercial species and added-value products for construction.

\section{Selected species}

Calycophyllum spruceanum (capirona) was selected due to its wood, which, according to Sibille's (2006) report, has an elevated basic density $\left(0.76 \mathrm{~g} / \mathrm{cm}^{3}\right)$ and a very low silica content $(0.14 \%)$.

\section{Tooth shapes of bandsaw blades}

The tooth profiles of the hook (NV) and skip (NU) types, presented in Figure 1, and prepared according to the characteristics of Table 1, were employed. They correspond to a tooth geometry basically differentiated in the chip exit angle and swaging width. Both shapes have been used to cut Amazonian species logs, with different tooth angles, regardless of the wood's density and hardness. The hook type is traditionally employed in sawmills of Pucallpa, as the skip profile, although when introduced in Pucallpa, it was not widespread due to its flat throat, which demands a very careful sharpening. 


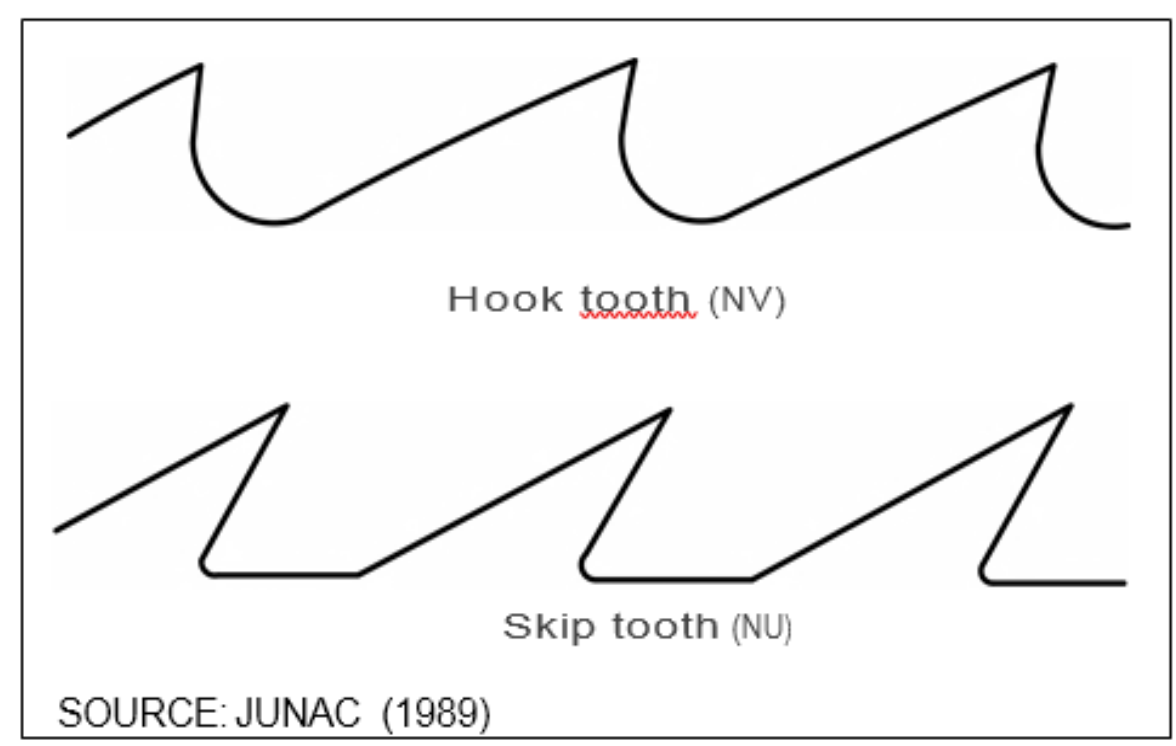

Figure 1 - Tooth profiles used to cut the Calycophyllum spruceanum wood

\section{Block resawing}

In a vertical-blade resaw with a wheel of $1.10 \mathrm{~m}$ of diameter, 12 Capirona blocks were resawed using two blocks of $150 \times 150 \times 3000 \mathrm{~mm}$ by tree, one basal and one intermediary, providing a sample of six blocks for each tooth shape prepared in a PREMIUM blade of $127 \times 1.1 \mathrm{~mm}$.

Six cuts of $150 \mathrm{~mm}$ high were performed in each block to measure the cutting power, corresponding to three feed speeds by each tooth shape, employing a power evaluator of the clampn type connected to the board of the machine's three-phase electric motor. With the feed speeds set in 9, 16, and $22 \mathrm{~m} / \mathrm{min}$ and assigned as low, medium, and high, it was possible to differentiate the chip thicknesses in the thin, medium and thick levels, respectively.

For each cutting line, the following variables were calculated: current intensity $(A)$, voltage $(V)$, vacuum power and cutting power $(\mathrm{kW})$. Then, the vacuum power was subtracted from the cutting power to estimate the useful power (W).

In the block resaw test, at every three cuts, the peripheral speed of the blade was measured in $\mathrm{m} / \mathrm{min}$ with a digital tachometer to establish their mean and variation. Additionally, each cutting line was timed to verify the feed speeds (Va) expected in the test, to which Equation 1 was applied.

$V a=\frac{\text { length of theblock }}{\text { timeby cutting line }}(\mathrm{m} / \mathrm{min})$

The trees 1, 3, and 5 were selected to test the hook tooth profile; on the other hand, the trees 2, 4, and 6 were employed for the skip tooth. Moreover, for each resawed block, $150 \mathrm{~g}$ of sawdust were collected to determine its silica content, applying the suggestions of the Technical Association of the Pulp and Paper Industry (TAPPI) (Technical Association of the Pulp and Paper Industry, 2007), and 12 specimens of $20 \times 50 \times 150 \mathrm{~mm}$ were prepared to first determine their Janka side hardness, according to the National Institute of Quality (INACAL) (National Institute of Quality, 2014), with changes in the specimen thickness and, then its moisture content and density in specimens of $20 \times 20 \times 30 \mathrm{~mm}$, according to the rules of the International Organization for Standardization (ISO) (International Organization for Standardization, 2014a, 2014b): ISO/FDIS 13061 parts 1 and 2, respectively. 
Table 1 - Geometric characteristics of the hook and skip tooth shapes

\begin{tabular}{ccc}
\hline Geometric characteristic & \multicolumn{2}{c}{ Tooth shape } \\
\cline { 2 - 3 } Pitch $(\mathrm{mm})$ & HOOK & SKIP \\
\hline Tooth height $(\mathrm{mm})$ & 38.0 & 38.0 \\
Gullet area $\left(\mathrm{mm}^{2}\right)$ & 11.5 & 11 \\
Swaging width $(\mathrm{mm})$ & 278.3 & 272.4 \\
Rake angle (degrees) & 2.71 & 2.63 \\
Sharpness angle (degrees) & 26 & 21 \\
Clearance angle (degrees) & 44 & 47 \\
\end{tabular}

\section{Variable calculation}

The data collected during the resaw test were typed into an EXCEL spreadsheet to calculate the study's variables-feed speed, chip thickness, and useful power-, from which were calculated the statistic mean, standard deviation, and coefficient of variation. For each cutting line, the chip thickness was established through Equation 2 (Sales, 1990; Gonçalves, 2000).

$E V=\frac{p x V a}{V c}$

Where EV = chip thickness $(\mathrm{mm})$

$\mathrm{p}=\operatorname{pitch}(\mathrm{mm})$

$\mathrm{Va}=$ feed speed $(\mathrm{m} / \mathrm{min})$

Vc $=$ cutting speed $(\mathrm{m} / \mathrm{min})$

\section{Experimental design and statistical analysis}

The data of cutting power related to the capirona wood were analyzed with the assistance of the R program, version 3.2.5. Once the data's normality was verified through the ShapiroWilk Test, their analysis of variance (ANOVA) was performed at a level of $95 \%$ of probability, applying a completely randomized design with the factorial arrangement of $2 \mathrm{~A} \times 2 \mathrm{~B} \times 3 \mathrm{C}$, with six repetitions, considering the tooth shape as the first factor, the level of the commercial stem height as the second factor, and the chip thickness as the third factor. When ANOVA presented a significant result $(P>0.05)$, Tukey's test was performed to compare means.

\section{RESULTS AND DISCUSSION}

\section{Characteristics of the cutting tool and of the Calycophyllum spruceanum wood}

Table 2 presents the features of the $C$. spruceanum wood that somehow affect its cutting process, regardless of the tooth shape employed, noticing a high density and side hardness, and a low silica content, and which stands out due to its great coefficient of variation.

Table 2 - Characteristics of the Calycophyllum spruceanum wood related to its cutting process

\begin{tabular}{ccccc}
\hline Characteristic & Mean & CV (\%) & $\begin{array}{c}\text { Minimum } \\
\text { value }\end{array}$ & $\begin{array}{c}\text { Maximum } \\
\text { value }\end{array}$ \\
\hline Moisture content (\%) & 47.81 & 7.08 & 45.89 & 49.72 \\
Green density $\left(\mathrm{g} / \mathrm{cm}^{3}\right)$ & 0.96 & 3.10 & 0.94 & 0.98 \\
Basic density $\left(\mathrm{g} / \mathrm{cm}^{3}\right)$ & 0.64 & 2.71 & 0.63 & 0.65 \\
Side hardness $\left(\mathrm{kg} / \mathrm{cm}^{2}\right)$ & 708.52 & 4.23 & 691.55 & 725.50 \\
Silica content $(\%)$ & 0.20 & 61.22 & 0.13 & 0.27 \\
\hline
\end{tabular}


Generally, Table 1 supports Carmo et al. (2014) statement in Peru. According to them, in the several tooth profiles employed to saw wood in Brazil, only the tooth's height is usually varied, and sometimes the chip exit angle. Nonetheless, one can notice that the hook tooth shape is slightly different from the skip type due to its greater gullet area and swaging width. Table 2 shows that the basic density of the wood under study was lower than the values of 0.895 and $0.76 \mathrm{~g} / \mathrm{cm}^{3}$, respectively reported by Paula \& Costa (2011) and Sibille (2006), possibly due to the age of the wood originated from a 20-year-old plantation, although the resulting values for side hardness and silica content were greater than the ones reported by the last author. *

According to Cristóvão et al. (2012) in his study about the cutting strengths of the wood, its density is used as an important indicator of wood rigidity, resistance, and hardness. Woods with side hardness levels above $600 \mathrm{~kg} / \mathrm{cm}^{2}$ can be classified as hard according to Tortorelli's (2009) scale. As for the silica content, Molina \& Del Castillo (2007) estimate that $0.5 \%$ results in a significant abrasion of the cutting elements; that is why the capirona wood can be considered as little abrasive, even with its maximum silica content of $0.27 \%$.

\section{Test conditions for the Calycophyllum spruceanum wood}

Table 3 presents the cutting conditions for the C. spruceanum wood during the block resawing at a cutting height of $15 \mathrm{~cm}$, employing the hook and skip tooth shapes, and three feed speed levels (low, medium, and high) that generated three chip thickness levels (thin, medium, and thick).

Table 3 - Cutting variables for the Calycophyllum spruceanum wood

\begin{tabular}{ccccc}
\hline Variable & Mean & CV (\%) & $\begin{array}{c}\text { Minimum } \\
\text { value }\end{array}$ & $\begin{array}{c}\text { Maximum } \\
\text { value }\end{array}$ \\
\hline $\begin{array}{c}\text { Cutting speed }(\mathrm{m} / \mathrm{min}) \\
\text { Feed speed }(\mathrm{m} / \mathrm{min})\end{array}$ & 944.15 & 13.14 & 894.5 & 993.8 \\
$\cdot$ Low & & & & \\
$\cdot$ Medium & 8.76 & 10.09 & 8.41 & 9.11 \\
$\cdot$ High & 16.09 & 6.17 & 15.69 & 16.49 \\
Chip thickness $(\mathrm{mm})$ & 22.32 & 3.78 & 21.99 & 22.66 \\
$\cdot$ Thin & & & & \\
$\cdot$ Medium & 0.35 & 10.09 & 0.34 & 0.37 \\
$\cdot$ Thick & 0.65 & 6.17 & 0.63 & 0.66 \\
Kerf width (mm) & 0.90 & 3.78 & 0.88 & 0.91 \\
$\cdot$ Hook profile & & & & \\
$\cdot$ Skip profile & 2.91 & 5.85 & 2.83 & 2.99 \\
& 2.70 & 5.66 & 2.62 & 2.77 \\
\hline
\end{tabular}

In Table 3, one can appreciate that the greatest variability was related to the cutting speed, which varied from 894 to $994 \mathrm{~m} / \mathrm{min}$ (14.9 to $16.6 \mathrm{~m} / \mathrm{s}$ ) due to sporadic voltage drops, with a mean of $15.7 \mathrm{~m} / \mathrm{s}$, which is equivalent to $45 \%$ of the speed proposed by Garcia et al. (2002) for hardwoods. Nevertheless, the lowest variability was related to the chip thickness, which was classified as thick, with a variation level of 0.88 to $0.91 \mathrm{~mm}$.

The fluctuation in the cutting speed can be considered irrelevant according to the conclusions of Dalois (1990) and Sales (1990) that the cutting effort has little variability in the cutting speed range of 5 to $50 \mathrm{~m} / \mathrm{s}$ for chip thicknesses between 0.5 to $1.5 \mathrm{~mm}$. One can also see that the feed speeds are within the range of 10 to $30 \mathrm{~m} / \mathrm{min}$ recommended for hardwoods by Dalois (1990) and Garcia et al. (2002), although the lower speed might be a little different.

As for the mean chip thicknesses corresponding to the mean feed speeds of 8.8, 16.1, and $22.3 \mathrm{~m} / \mathrm{min}$, they can be respectively classified as thin $(0.35 \mathrm{~mm})$, medium $(0.65 \mathrm{~mm})$, and thick $(0.90 \mathrm{~mm})$, finding themselves in the optimal values of 0.3 to $1.5 \mathrm{~mm}$ proposed by 
Garcia et al. (2002) for hardwoods, which, if thin, are slightly above the ones achieved by Carmo et al. (2014) while sawing a high density wood, such as Dipteryx odorata.

Nevertheless, the medium and thick chips are out of the range of the 0.15 to $0.6 \mathrm{~mm}$ established by Vignote and Martinez (2006) for increased energy saving. According to the proper cut zone for tropical woods defined by Sales (1990), thin chips do not reach the lower limit of $0.5 \mathrm{~mm}$ that Dalois (1990) considers advantageous for sawing hardwoods due to a lower wearing of the teeth.

As for the kerf width, the hook profile resulted in grooves that were above the $8 \%$ of the skip profile due to the greater swaging width of the tooth hook seen in Table 1, which is $0.04 \mathrm{~mm}$ smaller than the tooth width employed by Melendez \& Valenzuela (2017) in the sawing of $C$. spruceanum with a similar profile. It should be underscored that the swaging width of each side varied from 0.77 to $0.81 \mathrm{~mm}$ for the skip and hook profiles, respectively, which doubles the limits established for this type of wood by JUNAC (Cartagena Agreement Board, 1989), and Tuset \& Duran (2007).

\section{Useful cutting power for the Calycophyllum spruceanum wood}

Table 4 presents the analysis of variance of the real power consumed to cut the C. spruceanum wood employing two tooth profiles and three chip thickness. Table 5 presents the comparison between the useful cutting power means and their coefficient of variation corresponding to the tooth profiles and chip thicknesses evaluated.

Table 4 - Analysis of variance of the useful cutting power for the Calycophyllum spruceanum wood with two tooth profiles and three chip thicknesses.

\begin{tabular}{cc} 
Variation source & Significance of $\mathbf{F}$ \\
\hline Factor A: tooth profile & $20.9853^{* * *}$ \\
Factor B: level of the commercial stem height & $9.9097^{* *}$ \\
Factor C: chip thickness & $262.8019^{* * *}$ \\
Interaction: A x B & $0.0004^{\text {n.s. }}$ \\
Interaction: B x C & $1.1939^{\text {n.s. }}$ \\
Interaction: A x C & $10.2640^{* * *}$ \\
Interaction: A x B x C & $0.4021^{\text {n.s. }}$ \\
\hline
\end{tabular}

n.s. Not significant at a $5 \%$ level of probability $(p>.05)$ ** significant at a $1 \%$ level of probability $(.001 \leq p<.01) * * *$ significant at a $0.1 \%$ level of probability $(0 \leq p<.001)$

Table 5 - Mean values of real cutting power for the Calycophyllum spruceanum wood with two tooth profiles and three chip thicknesses.

\begin{tabular}{|c|c|c|c|c|c|}
\hline \multirow{2}{*}{$\begin{array}{l}\text { Tooth } \\
\text { profile }\end{array}$} & \multirow{2}{*}{$\begin{array}{c}\text { Commercial } \\
\text { stem }\end{array}$} & \multicolumn{3}{|c|}{ Real cutting power (W) by chip thickness } & \multirow{2}{*}{ General mean } \\
\hline & & Thin & Medium & Thick & \\
\hline \multirow{2}{*}{ Hook } & Basal & $3135.88 \mathrm{f}(11.45)$ & 4491.27 c (7.26) & 5198.38 a (6.64) & $4275.18(21.94)$ \\
\hline & Intermediate & $2942.97 f(5.61)$ & $4342.82 \mathrm{~cd}(6.56)$ & $4947.22 \mathrm{ab}(6.05)$ & $4077.67(21.99)$ \\
\hline $\begin{array}{c}\text { General } \\
\text { mean }\end{array}$ & & $3039.43(9.37)$ & $4417.05(6.84)$ & $5072.82(6.60)$ & $4176.42(21.79)$ \\
\hline \multirow{2}{*}{ Skip } & Basal & $3214.62 f(11.45)$ & 3958.15 de (6.97) & 4792.10 bc (2.89) & $3988.29(17.86)$ \\
\hline & Intermediate & $3092.07 \mathrm{f}(0.90)$ & 3901.72 e $(4.40)$ & 4385.57 c (3.74) & $3793.12(14.87)$ \\
\hline $\begin{array}{c}\text { General } \\
\text { mean }\end{array}$ & & $3153.34(8.15)$ & $3929.93(5.63)$ & $4588.83(5.60)$ & $3890.71(16.48)$ \\
\hline
\end{tabular}

Where: Means followed by the same lowercase letter presented no statistical difference between themselves through Tukey's test at $5 \%$ of probability. *Values in parentheses are the coefficients of variation of the means.

Table 4 shows that the tooth profile and the chip thickness significantly affected the useful cutting power at a level of $0.1 \%$ of probability. On top of that, an interaction between 
the tooth profile and the chip thickness is displayed with the change of tendency in the chart of Figure 2. Although the level of the commercial stem height also affected the cutting power of the block significantly, it did not display a joint action with the tooth profile or with the chip thickness, and for that reason, it did not interact with neither factor.

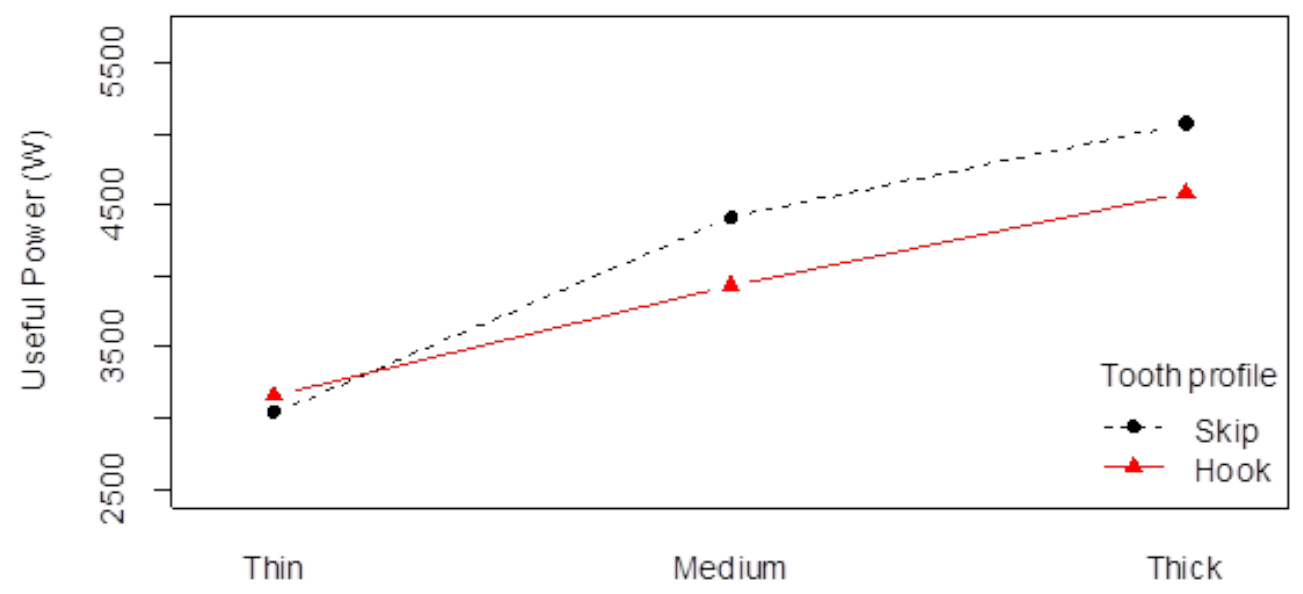

Chip thic kness

Figure 2 - Tooth profile interaction with the chip thickness for the useful cutting power in Calycophyllum spruceanum wood

Table 5 shows that the useful cutting power for the thin chips did not vary significantly between the tooth profiles and the level of the commercial stem height, indicating that the power values obtained with the hook and skip tooth shapes in the basal and intermediate levels were similar. On the other hand, for the medium and thick chips, the cutting power registered a sharper difference with the tooth profile than with the level of the commercial stem height. Sales (1990) attributes the increase of the cutting effort based on a given chip thickness with a tooth geometry to the following reasons:

- the mechanical action of the kerf's side walls is easily transmitted to the whole chip with the increase of its thickness

- the increase in the side friction induced by the compression of the sawdust on the tooth's gullet due to its saturation.

Analyzing Figure 3, one can notice, regarding the skip profile, that the use of the hook tooth, regardless of its swaging width, generates a significant increase of useful power during the resaw of the $C$. spruceanum, species, when medium and thick chips are cut. On the other hand, the cutting power is slightly reduced with thin chips.

The tendency described for useful power with the change of the tooth shape corresponds to a particularly subtle cutting power because a rake angle favorable to the incision does not necessarily improve the cutting effort. This effect can be attributed to the action of the hook tooth's gullet, which stops the sliding of the chip outside the cutting face, forcing its flexion and drastic partitioning into sawdust particles; on the other hand, the skip tooth's gullet facilitates the chip's sliding and its soft flattening, causing its progressive fragmentation. This behavior is supported by Sales's (1990) explanation that the curvature of the tooth's gullet, roughly seen, favors the fragmentation of the chip into small sawdust particles.

By means of the useful power reduced to one tooth to remove a volume of chips, in addition to the heterogeneity and anisotropy of the wood, the effect of the different edge length in both profiles and the variability of the thickness in the classified chips can be abstracted, allowing a better quantification of the energy advantage of the skip tooth over the hook tooth when this power is associated with the surface of wood sawn by the saw in $\mathrm{m}^{2} / \mathrm{min}$. The $3,8 \%$ energy saving achieved by the skip tooth with thick chips, in industrial terms 
represents a power consumption of $0.059 \mathrm{~kW} / \mathrm{m}^{2} / \mathrm{min}$ of sawn surface, which in one hour of effective work means an economy of $3,54 \mathrm{~kW} / \mathrm{m}^{2}$. These savings may have an impact on the competitiveness of the sawmill industry in the region that processes hardwoods with thin to medium chip thicknesses, when with the skip profile you could try cutting thick chips to reduce blunt and increase productivity with a higher feed speed.

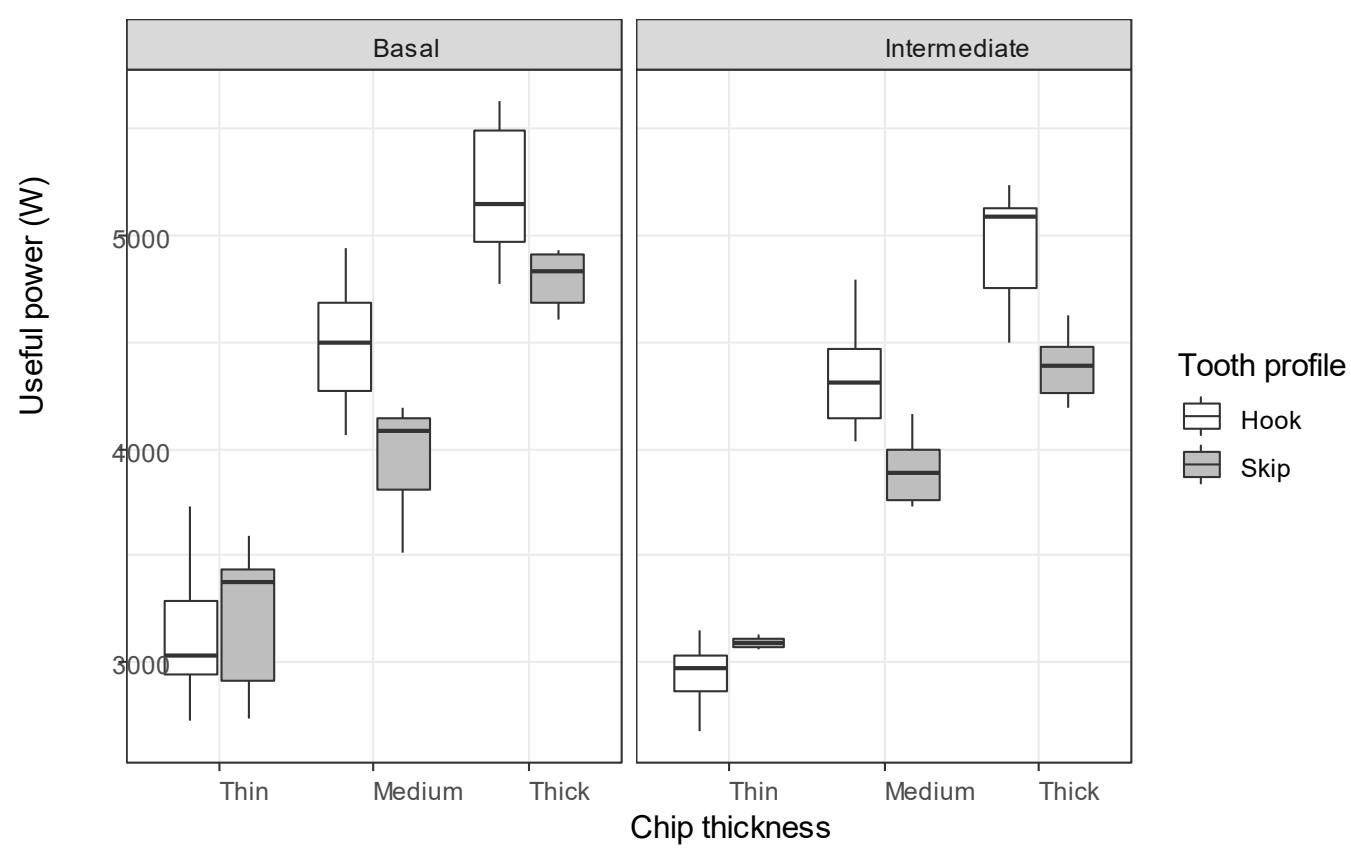

Figure 3 - Mean useful power to cut the Calycophyllum spruceanum wood with two tooth profiles and three chip thicknesses

\section{CONCLUSIONS}

Through the evaluations of the cutting power in the resawing of capirona wood from a 20-year-old plantation, with two tooth profiles for three chip thicknesses, one can conclude that:

- The effect of the tooth geometry in the cutting power is noticeable on the studied wood and characterized by its hardness, little abrasiveness, and high basic density;

- The power consumption necessary to cut the wood under study with medium and thick chips is reduced when the tooth shape is changed from hook to skip;

- The power consumption in the cut with thin chips increases when the tooth shape is changed from hook to skip, although the difference that favors the hook tooth is not significant;

- In spite of its greater rake angle, the hook tooth shape consumes more energy to cut the capirona wood. On the other hand, the skip tooth registers lower energy consumption with a smaller rake angle;

- The level of the commercial stem height only affects the cutting powers for thick chips, causing a slight increase when it is descending from the intermediate level to the basal, regardless of the tooth shape employed;

- The energy savings achieved with the skip tooth has a greater industrial impact on hardwood sawmills in the region, which can improve their productivity by cutting thick chips to increase the sawn surface in the unit of time.

\section{ACKNOWLEDGMENTS}

To the Gestón Maderera SAC company for allowing this research though the use of its facilities and factory staff. 


\section{BIBLIOGRAPHIC REFERENCES}

Araújo, B. P., Sousa, M. R., Nascimento, H. M., Zanuncio, A. V., Rodrigues, D. S., \& Guedes, M. C. (2016). Propriedades físicas da madeira de Calycophyllum spruceanum Benth. em função do diâmetro e da posição (base e topo) no fuste. Scientia Forestalis, 44(111), 759-768. http://dx.doi.org/10.18671/scifor.v44n111.22.

Carmo, J. F., Latorraca, J. V. F., Rocha, M. P., \& Brito, E. O. (2014). Influência da geometria dos dentes das lâminas de serra de fita na qualidade e produtividade da madeira serrada. Floresta, 44(2), 291-302. http://dx.doi.org/10.5380/rf.v44i2.28958.

Cartagena Agreement Board - JUNAC. (1989). Manual del Grupo Andino para Aserrío y Afilado de Sierras Cintas y Sierras Circulares (309 p.). Cali, Colombia: PRID-MADERA.

Cristóvão, L., Broman, O., Gronlund, A., Ekevad, M., \& Sitoe, R. (2012). Main cutting force models for two species of tropical Wood. Wood Material Science \& Engineering, 7(3), 143-149. http://dx.doi.org/10.1080/17480272.2012.662996.

Dalois, C. (1990). Manuel de Sciage et d'Affûtage (199 p.). Nogent-sur-Marne, France: Centre Technique Forestier Tropical.

Forest Institute. (1989). Principios de organización y operación del aserradero (Manual № 16, 217 p.). Concepción, Chile: Corporación de Fomento de la Producción.

Garcia, L., Guindeo, A., Peraza, C., \& De Palacios, P. (2002). La madera y su tecnología (322 p.). Madrid, Spain: Ediciones Mundi-prensa.

Gonçalves, M. T. T. (2000). Processamento da madeira (245 p.). Bauru, SP: M. T. T. Gonçalves.

International Organization for Standardization - ISO. (2014a). ISO/FDIS 13061-1: Determination of moisture content for physical and mechanical tests (4 p.). Geneva, Switzerland: ISO.

International Organization for Standardization - ISO. (2014b). ISO/FDIS 13061-2: Determination of density for physical and mechanical tests (6 p.). Geneva, Switzerland: ISO.

Lluncor, D., Roeder, O., \& Ypushima, A. (2006). Comportamiento al maquinado de la madera de Calycophyllum spruceanum BENTH HOOK. F. EX SCHUM. (Capirona) de Pucallpa. Revista Forestal de Ucayali, 3(1), 11-19.

Melendez, M., \& Valenzuela, W. (2017). Parámetros Básicos de Aserrado con Sierra Cinta para la Capirona Calycophyllum spruceanum. Revista Forestal del Perú, 32(1), 37-44. http://dx.doi.org/10.21704/rfp.v32i1.1035.

Molina, J., \& Del Castillo, L. (2007). Afilado y mantenimiento de sierra cinta de aserradero (26 p.). Lima, Peru: CITEmadera.

National Institute of Quality - INACAL. (2014). NTP 251.015: Madera. Método de determinación de la dureza (6p.). Lima, Peru: INACAL.

Paula, J. E., \& Costa, K. P. (2011). Densidade da madeira de 932 espécies nativas do Brasil (238p.). Porto Alegre: Ed. Cinco Continentes.

Sales, C. (1990). La scie a ruban: théorie et pratique du sciage des bois em grume (152 p.). France: Centre Technique Forestier Tropical, Nogent-sur-Marne.

Sibille, M. A. M. (2006). Guía de procesamiento industrial. Fabricación de Muebles con Maderas Poco Conocidas-LKS: Capirona (17 p.). Lima, Peru: USAID/PROMPEX.

Technical Association of the Pulp and Paper Industry - TAPPI. (2007). T $245 \mathrm{~cm}$-07: silicates and silica in pulp (Wet Ash Method, 3 p.). Atlanta, USA: TAPPI.

Technological Innovation Center of Wood - CITE Madera. (2012). Buenas Prácticas en la Operación y Mantenimiento de la Sierra Cinta del Aserradero (74 p.). Lima, Peru: CITE madera.

Tortorelli, L. (2009). Maderas y bosques argentinos (Tomo I, 515 p.). Buenos Aires, Argentina: Orientación Gráfica Editora.

Tuset, R., \& Duran, F. (2007). Manual de maderas comerciales, equipos y proceso de utilización. Aserrado de maderas (370 p.). Montevideo, Uruguay: Ed. Hemisferio-Sur.

Vignote, S., \& Martinez, I. (2006). Tecnología de la madera (678 p.). Madrid, Spain: Ediciones Mundi-Prensa. Vital, B. R. (2013). Planejamento e operação de serrarias (211 p.). Viçosa: Editora Universidade Federal de Viçosa.

Authors' contributions: MMC: Conceptualization, Investigation, Methodology, Resources, Writing - original draft, Writing - review \& editing; RMM: Formal analysis, Software, Writing - review \& editing; HGM: Conceptualization, Methodology, Writing - review \& editing; RJK: Investigation, Methodology, Supervision, Writing - review \& editing; MPR: Conceptualization, Methodology, Resources. 